\title{
The Nila Nyat-nyat, Balinese Special Food Contains Good Nutrition and High Organoleptic Quality
}

\author{
I Gde Suranaya Pandit ${ }^{1}$, Pande Ayu Naya Kasih Permatananda ${ }^{2}$ \\ \{ suranaya_pandit@yahoo.com ${ }^{1}$, nayakasih@gmail.com $\left.{ }^{2}\right\}$ \\ Universitas Warmadewa, Bali, Indonesia
}

\begin{abstract}
Tilapia is a freshwater fish whose production has increased in recent years, so that local people in Bali process tilapia into Nila Nyat-nyat which is a typical Balinese culinary. Nila nyat nyat is cooked through boiling process with Balinese herbs for 30 minutes. This study is aimed to know the process of making Nila Nyat-nyat in a restaurant near Sangeh tourist village, Badung regency, Bali. Nila nyat-nyat which has been processed, then taken to the laboratory to analyze its nutritional content includes water, protein, fat, ash content, and its organoleptic quality. The analysis shows that Nila Nyat-nyat is very prospective to be a Balinese culinary because it has a distinctive taste and smell of specific spices. The nutrient content in Nila nyat-nyat includes $68.01 \%$ water, $19.66 \%$ protein, $1.03 \%$ fat, and $1.23 \%$ ash. The overall organoleptic value is very good with Balinese taste and smell.
\end{abstract}

Keywords: Nila nyat-nyat, Balinese culinary, nutritional content, organoleptic quality

\section{INTRODUCTION}

Fish is a highly nutritious food, rich in protein, especially essential amino acids, and various minerals such as phosphorus, magnesium, iron, zinc, and iodine. Also, fish is generally a good source of the B vitamins and, in the case of fatty species, of A and D vitamins. Fish is also a source of vitamins, namely vitamins $\mathrm{A}, \mathrm{B}$, and $\mathrm{D}$ and fish also contains a non-protein nitrogen fraction that affects the quality of fish. Fish is very popular with people because it is high in nutrition, tasty, and easy to digest. Therefore, fish become one of the commodities of trade in many countries in the world, especially developing countries. More than half of the population of developing countries depend on fish as animal protein intake, whereas in developed countries, only $20 \%$ of animal protein intake comes from fish [1].

The waters in Bali are very wide to reach $\pm 9.634,35 \mathrm{~km}^{2}$ and have very potential fisheries resources. The sustainable potential of fish resources in the sea is estimated at 147,278.75 tons per year consisting of pelagic fish 123,906.0 tons / year and demersal fish 23,372.75 tons / year. The 
amount of this potential does not include offshore and Indonesian Ocean waters. Land fisheries include public waters consisting of lakes, rivers, reservoirs and swamps which can be utilized for fisheries business $\pm 1,771,800$ Ha with an estimated potential of $\pm 1,500$ tons / year, cultivation of freshwater fish with potential land area for fish farming in ponds is $\pm 1,700.41 \mathrm{Ha}$ and rice fields are $\pm 25,242.06 \mathrm{Ha}$. Furthermore, the potential land area for brackish water cultivation (ponds) is $1,667.0 \mathrm{Ha}$ and in 2007 only $488 \mathrm{Ha}$ was utilized or $32.20 \%$ with a production of $2,896.70$ tons [2].

The Nile Tilapia (Oreochromis niloticus) in particular, is one of the fish types which is widely spread in Bali Province through cultivation process. It is belong to species of tilapia, a cichlid fish native to Africa from Egypt south to east and central Africa, and as far west as Gambia. It is also native to Israel, and numerous introduced populations exist outside its natural range for cultivation [2]. This cultivation process is known to have been conducted in several regencies in Bali, for example; Denpasar City with 1.8 tons of production, Badung with 90.1 ton of production, Tabanan with 567.12 tons of production, Jembrana with 28.31 tons of production, Buleleng with 61.9 tons of production, Karangasem with 218.0 tons of production, Klungkung with 6.6 tons of production, Gianyar with 24.20 tons of production, and Bangli with 882.0 tons of production [3]. Some types of fresh-water fish aside from Nile tilapia like tilapia fish, cat fish, groper fish, and carp are also highly nutritious. But different from the other fresh-water fish, Tilapia is a freshwater fish that is easy to maintain and not so much disease disorder. Tilapia nursery is quite easy. From a pair of brooders 250-1000 eggs can be produced. The preparation time from eggs to seeds of 5-8 cm takes 60 days. Tilapia includes as fast-growing fish. The time needed ranges from 4-6 months to cultivate tilapia until it is ready for consumption. The growth of male tilapia is faster than female fish. The growth of tilapia can even reach 4.1 grams per day. [4].

Nile Tilapia is a fresh-water-typed fish which are widely consumed by wide varieties of people due to their thicker meat compared with those of the tilapia fish and cat fish. Nile Tilapia fish have distinctive characteristics which can be differentiated from gold fish and alum fish by observing their vertical lines on their back fins and tail fins. A 100-gr fresh Nile Tilapia meat contains $19.8 \%$ protein, $2.7 \%$ fat, $74.8 \%$ water, $1.2 \%$ ash. Those chemical substances indicate that the fish are fine to consume by all ranges of age [5-8]. One of fish dishes made from the Nile Tilapia in Bali is called Nila Nyat-Nyat, which is cooked through certain processes involving a 30minute boiling step on a pot filled with boiling fresh water and some spices. The Nile Tilapia as the main ingredient must have the highest possible level of freshness in order to produce high quality of Nila Nyat Nyat. This article aims to explain the making process of the Nila Nyat - Nyat and show its nutritional content and organoleptic quality.

The research process was conducted through several phases. First phase was done through as survey in Sangeh tourist village, Badung regency as the pointed location where Nila Nyat-Nyat is made in order to directly observe the preparation process for the ingredients and utensils as well as the boiling process. The phase 2 was done by delivering the readily served Nila Nyat-Nyat to the laboratory at the Faculty of Agriculture Universitas Warmadewa in order to analyze and determine the chemical substances within the dish which include water level, protein, fat, and ash. The water level and the ash within the meat were determined by utilizing an exicator, while the level of protein and fat were determined through the Kjeldahl method and soxhlet respectively. The quality of organoleptic in terms of scent, texture, appearance, and taste were assessed by 3 independent panelists. The phase 3 as the last step was done to descriptively present and report the results of 
the observation which was then followed by publishing the analyses in the form of mean percentage table.

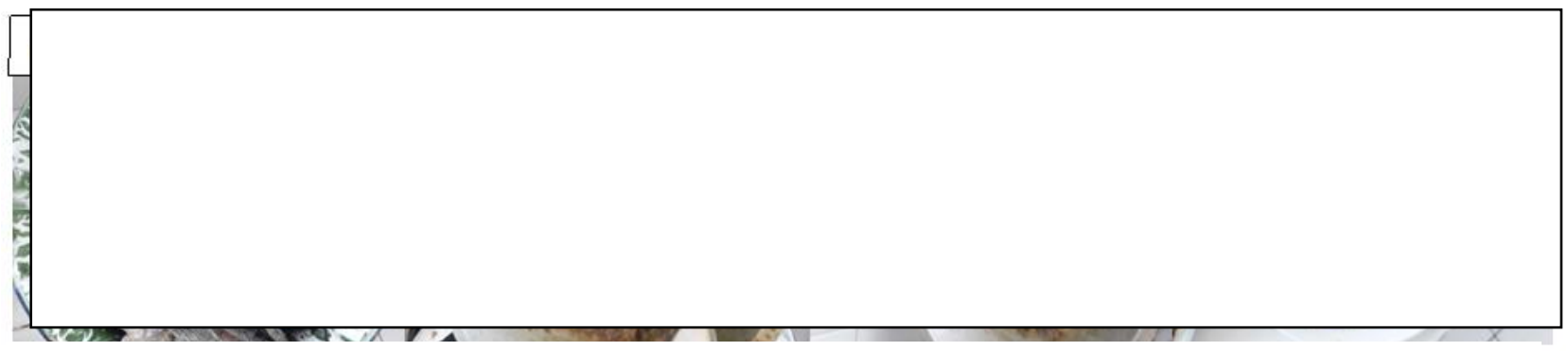

Figure 1. The Making Process of Nila Nyat-Nyat: Selected Nile Tilapia Fishes (a), Balinese Herbs and Spices (b). The Boiling Process (c). Nila Nvat-nvat readilv to be served (d).

\section{DISCUSSION}

\section{A. Characteristic of Nila Nyat-nyat and the Making Process}

Nowadays, fish is one of the most popular foods for people as a source of animal protein that is rich in nutrients. The composition of fish meat includes lower fat content and higher water content than cattle or chicken and tends to be preferred over chicken or white meat. The nutritional content of fish includes the contents of moisture, dry matter, protein, lipids, vitamins and minerals. Minerals are nutrients that are very important especially for the formation of enzymes and metabolic processes that contribute to growth. Mineral deficiencies will cause many disorders, reduce productivity and cause disease [5].

Nile Tilapia is one fresh water fishes which has high consumption value in the wide varieties of consumer. Its body structure is long and flat which comes in either blackish white or reddish white. The benefits of cultivating tilapia include easy to culture, high growth rate, easy breeding, high fibrillate protein, good taste, white cotton meat, having more Omega-3 fatty acids than other wild freshwater fishes and wild estuarine fishes as well. These benefits then resulted in an increase in demand for tilapia, especially for reasons of its low prices and high nutritional content. This trend applies not only domestically but also to foreign exports [5].

Nile Tilapia is people's favorite fish due to its thick meat. Bali has 19 superior commodities in the field of fishery in which one of them is Nile Tilapia [3]. Nile Tilapia is an ingredient for various fish-based dishes and The Nila Nyat-Nyat is one of them which comes with Balinese traditional spices. This dish is cooked through boiling process lasting for 30 minutes. The selected fish for this dish must have high level of freshness which can be identified from the look of its clear and bulging eyes with clear corneas, clear red gills without any kinds of mucus, clear and transparent mucous layer without any color changes, clear and easy cut on the meat, real color on the meat with no red color along its spine, innards which are still intact and fresh, clear red kidneys, solidification on its body which results in the spine being difficult to take away but elastic when pressed on [9-10]. The observation on the making process of Nila Nyat-Nyat was performed in one of the restaurants in Sangeh. The fresh Nile Tilapia used in the making process of Nila Nyat-Nyat were obtained from The Feed Seed Hall in Sangeh, Badung Regency. The word nyat in 
the nickname Nila Nyat-Nyat means nearly dried off resulting from the boiling process which is supposedly done until the boiling water is nearly vaporized in order to maximize the flavor coming from the spices within the boiling water. The making process of this dish involved several steps, which was initiated by cleaning the selected Nile Tilapia by using fresh and clean water. The cleaned Nile Tilapia was then greased with lime before being fried until it was half-cooked. The next step was to slice the spices needed for the dish and then apply them on the half-cooked fried Nile Tilapia and put them all together in boiling water to start the boiling process. After approximately 30 minutes or when the water was nearly dried off, the dish was now placed on the proper plate and served.

Spices contribute a significant role to the taste of Nila Nyat-Nyat. There are generally two types of spice which can be complemented on the dish, which are Balinese spice or locally called as Base genep and Fragrance-based Spice or called Base Selem. The ingredients for The Base Genep and The Base Selem consist of garlic, union, chili, ginger, lemongrass, candlenut, coriander, and salt. Nila Nyat-Nyat which was ready to serve was then delivered to the laboratory in order to analyze the water level, protein, fat, and ash.

Spices contribute important aspects to the making process of the dish as they influence the taste of the dish itself. In addition, the spices are also useful in preserving the dish so it can last longer. Without the spices, the dish will likely to be tasteless. The ingredients of the spices consist of garlic which contains flavonoid, saponin, essential oil, phosphor, fat, iron, and alisine substance which causes garlics to have strong scent. The ingredients also consist of union which has distinctive substance called propyl disulfide causing unions to have distinctive scent. The other ones are chili with its capsaicin substance which causes it to be spicy, curcumin with its high antioxidant substance, lemongrass with its citronellol substance which functions as an antiseptic, candlenut which has been around in Indonesia for years, coriander with its high antioxidant substance which can decelerate the development of microorganisms and bacteria and extend the lifespan of the meat; as well as salt as an additional spice which can also preserve foods [11-12]. The Boiling process takes 30 minutes to complete. The duration of cooking process will influence the proximate composition like water, protein, ash, and fat content in a certain fish-based dish [8].

\section{B. Nutritional Content and Organoleptic Quality of Nila Nyat-nyat}

The result of laboratory analyses is presented in table 1 showing that Nila Nyat-Nyat which has been boiled for 30 minutes contains water, protein, fat, and ash which are similar to uncooked fresh Nile Tilapia. The organoleptic assessment on the dish was conducted by 3 independent panelists from which the average value on the appearance, odor, and taste was obtained above 7 , only the texture score was below 7 , as shown in table 2 .

Water content or humidity is defined as the amount of water contained in a material. Measurement of water content is very important because the water content greatly affects the organoleptic of fish, such as taste, texture, weight, appearance, and shelf life of fish. Just a slight shift in the value of the standard will greatly affect the physical appearance of a food material. For example, substances which are too dry could affect the consistency of the end product. Conversely, excess moisture may cause food material to agglomerate or become trapped in the piping systems during production. Also, the rate of microbial growth increases with total water content, possibly resulting in spoiled batches that need to be disposed of [13]. 
Table 1. Nutritional Content of Nila nyat-nyat

\begin{tabular}{l|ll|}
\hline Nutritional Parameter & Nila nyat-nyat & Fresh Nile Tilapia [2][5] \\
\hline Water (\%) & 68.01 & 74.8 \\
\hline Protein (\%) & 19.66 & 19.8 \\
\hline Fat (\%) & 1.03 & 2.7 \\
\hline Ash (\%) & 1.04 & 1.2 \\
\hline
\end{tabular}

Table 2. Organoleptic Assesment Result of Nila nyat-nyat

\begin{tabular}{l|l}
\hline Organoleptic & Mean Score \\
\hline Appearance & 7.87 \\
\hline Odor & 7.60 \\
\hline Texture & 6.87 \\
\hline Taste & 7.70 \\
\hline
\end{tabular}

The water content in the boiled Nile Tilapia decreases compared with fresh Nile Tilapia. The decrease occurs due to the water in the fish being sucked out by the salt in the boiling water. It also caused by the disintegration between the fish and its protein which is degraded because of the heat. The degraded protein results in the disintegration between protein and water molecule. Extreme heat occurring in the boiling process can lead to the fact that the body tissue of the fish can no longer maintain the process of the water coming in and out due to quality degradation [14-16]. Referring to the standard quality of boiled fish product in Indonesia which is based on Indonesia National Standard (SNI) 2717.1.2009 [13], the water level expected is not more than 60, whereas it was found that the water level is 68.01 in Nila Nyat-Nyat, which means that it is above the standard of product quality of boiled fish. High water content in a certain food will result in smooth texture which is considered degradation. In addition, it also provides more chances for the bacteria to develop, decreasing the lifespan of the food [14-15].

Ash is the inorganic residue remaining after the water and organic matter have been removed by heating in the presence of oxidizing agents, which provides a measure of the total amount of minerals within a food. Ash content represents the total mineral content in foods. Determining the ash content may be important for several reasons. It is a part of proximate analysis for nutritional evaluation. Ashing is the first step in preparing a food sample for specific elemental analysis. Because certain foods are high in particular minerals, ash content becomes important. One can usually expect a constant elemental content from the ash of animal products, but that from plant sources is variable. But, the ash content is not subject of assessment in SNI for boiled fish product. However, referring to meatball product, the ash content allowed based on the SNI 3818.01.1995 is below 3\% [17], whereas it was found that Nila Nyat-Nyat contains $1.04 \%$ of ash content. The ash content is referred to as an indicator of rottenness. The ash content in Nila Nyat-nyat indicates that there is inorganic mineral substance in the dish following the 30-minute boiling process. There is a relatively small degradation on the ash content of the dish compared with the fresh Nile Tilapia which suggests that heat received during the boiling process can only partly influence the mineral substance on the surface which is highly dependent of the amount of heart received [18-19].

Fish and processed fish provide valuable nutrients, likes easily assimilated proteins, with the digestibility of over $90 \%$ and necessary amino acids with a beneficial composition, which allows 
the body an optimum use of proteins. The protein in Nila Nyat-Nyat is found to be slightly lower than it is the fresh Nile Tilapia. Heats are recognized to be able to cut the hydrogen bond supporting the secondary and tertiary structure of a certain type of protein so the hydrophobic side and the side cluster of polypeptide will be open, resulting in the solubility of the protein decreasing and ending up settling down and agglomerating or known as coagulation. The concentration of protein is not a parameter to assessing the boiled fish-based dish either. However, it was discovered that the protein level in Nila Nyat-Nyat based on the SNI 3818.01.1995 [16] is 9\% at the minimum. The low level of protein in any dish results in less taste and less distinctive aroma; however, it does not mean that high level of protein is good either as it produces bad smell [14, 1819].

Like the other previous two components, the fat level is not subject to assessment based on SNI for boiled fish-based dish either. On the other hand, it was discovered that the fat level in Nila Nyat-Nyat is $1.03 \%$, which is appropriate with value of the recommendation from the SNI 3818.01 .1995 which is $2 \%$ at the maximum [17]. Generally, there is a certain amount of damage dealt to the fat after certain food processing, depending on the temperature during the process. The fat degradation level after the food processing is caused by the nature of fat itself where it is durable against heat. During the food processing, the fat melts and vaporizes into another component like taste. The main ingredient of the dish contains high level of fat which is $2.7 \%$. High level of fat in any fish-based processed food will quicken the occurrence of bad smell [14, 18-19].

Based on the SNI [17], boiled fish-based dish which has been through organoleptic assessment, should have value of 7 at the minimum. Through the organoleptic assessment, the odor, appearance, and taste are already considered to be based on the recommendation of the SNI due to them having value of above 7 . However, the texture assessment is not as good as the other aspects as it appears to be slightly the standard value 7, which is 6.87 . This discovery means that the texture is solid but not really compact and slightly mushy. The slightly soft texture on the dish is caused by the water level being slightly higher due to the longer duration during the boiling process which is 30 minutes. This duration during the boiling process is considered influential to the water level and texture of the fish [14-15].

\section{Conclusion}

Nile Tilapia is one of the superior commodities in the field of fishery in Bali. The fact that this fish has thicker than any other fishes makes it the most favorite fish. Nila Nyat-Nyat is a processed food combined with Balinese spices. Nila Nyat-Nyat, which is boiled within 30 minutes, has nutritious contents and good organoleptic quality.

\section{Acknowledgement}

The authors express the greatest gratitude to the organizing committee of the International Conference on Social Sciences (ICOSS) of Universitas Warmadewa for the great contribution that has been granted to the launching of this scientific script at EAI Publisher. We hope that the ideas found in the paper can be additional to the theoretical and practical konwledge for many parties. 


\section{References}

[1] S. Craig, "Understanding Fish Nutrition, Feeds, and Feeding," Virginia Cooperative Extension 420-256, pp 1-4, 2009.

[2] Dinas Kelautan dan Perikanan Propinsi Bali, "Potensi Perikanan di Bali," Bali, 2008.

[3] Dinas Kelautan dan Perikanan Propinsi Bali, "Statistik Perikanan Bali," Bali, 2015.

[4] FAO Fisheries and Aqua Culture, "Oreomichus niloticus," Rome, 2018.

[5] A. M. Fauzi, A. K. Fathia, H. M. Asaad, O. D. Obay, A. M. Ayman, "Body Weight Characteristics and Chemical Composition of Nile Tilapia Oreomicus niloticus Collected from 3 Different Sudanese Dams," IJFAS, vol 4, pp 507-510, 2016.

[6] M. Isa, Rinidar, T. Zalia, A. Harris, Sugito, Herrialtan, "Analisis Proksimat Kadar Lemak Ikan Nila yang Diberi Suplementasi Daun Jaloh yang Dikombinasi dengan Kromium dalam Pakan Setelah Pemaparan Sinar Panas," Jurnal Medika Veterania, vol 9, pp 60-63, 2015.

[7] Ramlah, E. Soekendarsi, Z. Hasyim, M. S. Hasan, "Perbandingan Kandungan Gizi Ikan Nila Asal Danau Mawang Kabupaten Gowa dan Danau Universitas Hassanudin Kota Makasar," Jurnal Biologi Makasar, vol 1, pp 39-46, 2016.

[8] R. Iskandar, S. Fitriani, "Analisa Proksimat Pakan Hasil Olahan Pembudidaya Ikan di Kabupaten Banjar Kalimantan Selatan,” ZIRAA’AH, vol 42, pp 65-68, 2017.

[9] S. M. Bostic, J. Sobal, C. A. Bisogni, J. M. Mandova, "Types and Characteristic of Fish and Seafood Provisioning Scripts Used by Rural Midlife Adults," Journal of Nutritional Education and Behavior, vol 54, pp 535-544, 2017.

[10] S. M. Elshehawy, A. A. E. Gab-Alla, H. M. Mutuwally, "Quality Attributes of the Most Common Consumed Fresh Fish in Saudi Arabia," IJNFS, vol 5, pp 85-94, 2016.

[11] I. Paur, M. H. Carlsen, B. L. Halvorsen, R. Blomhoff, "Antioxidants in Herb and Spices in Herbal Medicine," Biomolecular \& Clinical Aspects $2^{\text {nd }}$ ed, Oxfordshire, Taylor \& Francis Group, 2016.

[12] A. Yashin, Y. Yashin, X. Xia, B. Nemzer, "Antioxidant Activity of Spices and Their Impact on Human Health: A Review," Antioxidant J, vol 6, pp 1-18, 2017.

[13] H. Isengard, "Water Content, One of The Most Properties of Food," Food Control, vol 12, pp 395-400, 2001.

[14] D. N. Midayanto, S. S. Yuwono, "Penentuan Atribut Mutu Tekstur Tahu untuk Direkomendasikan sebagai Syarat Tambahan dalam Standar Nasional Indonesia," Journal Pangan dan Agroindustri, vol 2, pp 259-267, 2014.

[15] S. Al-Reza, S. Karmaker, M. Hasan, S. Roy, R. Hoque, N. Rahman, "Effect of Traditional Fish Processing Methods on the Proximate and Microbiological Characteristics of Proximate and Microbiological Characteristics of Laubuka dadiburjori During Storage at Room Temperature, “J. Fish Aquat. Sci, vol 10, pp 232-243, 2015.

[16] E. Masrifah, B. P. Noorachmat, A. Sukmawati, "Kesesuaian Penerapan Manajemen Mutu Ikan Pindang (Chanos chanos) terhadap Standar Nasional Indonesia," Manajemen IKM, vol 10, pp 163-172, 2015.

[17] Badan Standardisasi Nasional, "Standarisasi Nasional Indonesia," Jakarta, 2009.

[18] Anggiatani, Yusra, Y. Efendi, "Studi Mutu Ikan Bilih Asap di Beberapa Pasar di Kota Padang," Jurnal Katalisator, vol 1, pp 1-12, 2016.

[19] S. L. Rahmi, "Analisis Mutu Bakso Tusuk di kota Jambi Berdasarkan Standar Mutu SNI-013818-1995," Jurnal Penelitian Universitas Jambi Seri Sains, vol 17, pp 72-75, 2015. 